\title{
Benchmarking Cancer Centers: From Care Pathways to Integrated Practice Units
}

\author{
Anke Wind, PhD ${ }^{\mathrm{a}, \mathrm{b}}$; Francisco Rocha Gonçalves, $\mathrm{PhD}^{\mathrm{c}}$; Edit Marosi, MSc ${ }^{\mathrm{d}}$; Lucia da Pieve, MSc ${ }^{\mathrm{e}}$; \\ Monica Groza, MScf; Marco Asioli, MSc $c^{\mathrm{g}}$; Marco Albini, MSc ${ }^{\mathrm{h}}$; and Wim van Harten, MD, PhD ${ }^{\mathrm{a}, \mathrm{b}, \mathrm{i}}$
}

\begin{abstract}
Background: Structuring cancer care into pathways can reduce variability in clinical practice and improve patient outcomes. International benchmarking can help centers with regard to development, implementation, and evaluation. A further step in the development of multidisciplinary care is to organize care in integrated practice units (IPUs), encompassing the whole pathway and relevant organizational aspects. However, research on this topic is limited. This article describes the development and results of a benchmark tool for cancer care pathways and explores IPU development in cancer centers. Methods: The benchmark tool was developed according to a 13-step benchmarking method and piloted in 7 European cancer centers. Centers provided data and site visits were performed to understand the context in which the cancer center operates and to clarify additional questions. Benchmark data were structured into pathway development and evaluation and assessed against key IPU features. Results: Benchmark results showed that most centers have formalized multidisciplinary pathways and that care teams differed in composition, and found almost 2-fold differences in mammography use efficiency. Suggestions for improvement included positioning pathways formally and structurally evaluating outcomes at a sufficiently high frequency. Based on the benchmark, 3 centers indicating that they had a breast cancer IPU were scored differently on implementation. Overall, we found that centers in Europe are in various stages of development of pathways and IPUs, ranging from an informal pathway structure to a full IPUtype of organization. Conclusions: A benchmark tool for care pathways was successfully developed and tested, and is available in an open format. Our tool allows for the assessment of pathway organization and can be used to assess the status of IPU development. Opportunities for improvement were identified regarding the organization of care pathways and the development toward IPUs. Three centers are in varying degrees of implementation and can be characterized as breast cancer IPUs. Organizing cancer care in an IPU could yield multiple performance improvements.
\end{abstract}

Healthcare systems struggle with the rising cost of cancer care $^{1}$ and are increasingly under pressure to deliver highquality services. ${ }^{2}$ Cancer care is often provided across different settings and involves healthcare professionals from multiple disciplines, ${ }^{3}$ and therefore high-quality multidisciplinary care can be compromised by inadequate coordination. ${ }^{4}$ The implementation of care pathways has been shown to reduce variability in clinical practice and to improve

\footnotetext{
aDepartment of Psychosocial Research and Epidemiology, Netherlands Cancer Institute, Amsterdam, the Netherlands; 'bepartment of Health Technology and Services Research, University of Twente, Enschede, the Netherlands; 'Instituto Português de Oncologia do Porto, Porto, Portugal; International Office, National Institute of Oncology, Budapest, Hungary; eClinical Risk Management and Accreditation Unit, Centro di Riferimento Oncologico (CRO), IRCCS, National Cancer Institute, Aviano (Pordenone), Italy; ${ }^{\top}$ The Oncology Institute "Prof. Dr Ion Chiricuta" Cluj-Napoca, Cluj-Napoca, Romania; "Scientific Directorate, Fondazione IRCCS Istituto

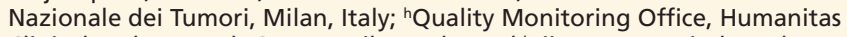
Clinical and Research Center, Milan Italy; and 'Rijnstate Hospital, Arnhem, the Netherlands.

Submitted March 14, 2017; accepted for publication April 18, 2018.

Drs. Wind and van Harten have disclosed that they have received grant/
}

outcomes. "Clinical/Care pathways," with varying nomenclature such as critical pathways, integrated care pathways, case management plans, and care maps, are used to systematically manage a patient-focused care program. ${ }^{6}$ Although clinician views on purpose, content, and implementation diverge, ${ }^{7}$ consensus exists on pathway characteristics: it should have strong multidisciplinary character aimed at improving quality and efficiency, and strong emphasis

research support from Novartis. Dr. da Pieve has disclosed that she was employed by INTENT (effective until May 2018). The remaining authors have disclosed that they have no financial interests, arrangements, affiliations, or commercial interests with the manufacturers of any products discussed in this article or their competitors.

Author contributions: Study concept and design: Wind, Gonçalves, Marosi, da Pieve, Groza, Asioli, van Harten. Data acquisition: Wind, da Pieve, Marosi, Groza, Asioli, Albini. Data analysis and interpretation: Wind, Gonçalves, Marosi, van Harten. Manuscript preparation: Wind, van Harten. Critical revision: Gonçalves, Marosi, da Pieve, Groza, Asioli, Albini, van Harten. Correspondence: Wim van Harten, MD, PhD, Department of Health Technology and Services Research, University of Twente, PO Box 217, 7500 $A E$, Enschede, the Netherlands. Email: w.v.harten@nki.nl 
Wind et al

on alignment issues throughout the care chain for a homogeneous patient group. Vanhaecht et $\mathrm{al}^{8}$ showed that improvement in care pathway concepts and methodology demand international knowledge-sharing, which can be facilitated by international benchmarking (eg, on specific topics such as information technology integration). According to Polite et $\mathrm{al},{ }^{9}$ oncology pathways offer many potential advantages; nevertheless, several issues must be addressed, such as who should control the development of pathways.

A recent development in healthcare is the transformation from volume-based to value-based care. ${ }^{10}$ In terms of value (ie, patient health benefits per healthcare dollar spent), ${ }^{11}$ most current models lack (1) an ability to measure outcomes that matter to patients, (2) transparency around measured clinical and financial outcomes, and (3) care coordination across all providers in the care pathway. According to Porter and Teisberg, ${ }^{10}$ transformation to value-based healthcare requires a shift from silos organized by specialty to care organized around a patient's medical condition, including the whole pathway. They propose integrated practice units (IPUs), in which a team of clinical and nonclinical personnel provides the full care pathway. ${ }^{10}$ Wherever IPUs exist, consistent results are found, including faster treatment, better outcomes, and lower costs. ${ }^{1}$ An example of IPU development in cancer care is the multidisciplinary care centers at MD Anderson Cancer Center. ${ }^{12}$ However, research regarding this subject is limited.

The primary goal of the present study was to describe the development and outcomes of a benchmark tool for oncology care pathways. Benchmarking is defined as the continual and collaborative measuring and comparing of results of key work processes with those of the best performers. ${ }^{13}$ Learning how to adapt these best practices can help achieve breakthrough process improvements and build healthier communities. ${ }^{13}$ The secondary goal was to explore the degree of IPU development in cancer centers based on the benchmark data.

\section{Methods}

\section{Study Design}

This international benchmarking study-part of the BENCH-CAN project, ${ }^{14}$ a European project aimed at benchmarking cancer care to contribute to improving the quality of interdisciplinary patient treatment-involved 7 European cancer centers (4 in South Europe and 3 in Central/East Europe). Participating cancer centers were members of the Organisation of European Cancer Institutes (OECI), and 5 were designated Comprehensive Cancer Centers by the OECI. ${ }^{15}$ The benchmark tool used to collect data was developed and executed according to the 13 steps developed by van Lent et $\mathrm{al}^{16}$ (Table 1). Steps 7 through 12 are further elaborated in the following section.

\section{Indicator Development and Collection}

Indicators (step 7) were derived from the literature and expert opinion. Experts included a representative from the Netherlands Comprehensive Cancer Organisation (IKNL), who was researching pathways in oncology,

\begin{tabular}{|c|c|c|}
\hline Step & Action & Application in This Study \\
\hline 1 & Determine what to benchmark & Organizational aspects of pathways and tumor services \\
\hline 2 & Form a benchmarking team & BENCH-CAN consortium \\
\hline 3 & Choose benchmarking partners & 7 cancer centers in South and Central/East Europe \\
\hline 4 & Define and verify the main characteristics of the partners & $\begin{array}{l}\text { Mapping exercise of the external environment of the cancer centers and the influence this could } \\
\text { have on the pathway and tumor service development }\end{array}$ \\
\hline 5 & Identify stakeholders & Patients, clinicians, administrators, and researchers \\
\hline 6 & Construct a framework to structure the indicators & This was not specifically done for this study; framework of the BENCH-CAN project was used ${ }^{14}$ \\
\hline 7 & Develop relevant and comparable indicators & $\begin{array}{l}\text { Based on literature and expert opinion (from cancer centers and an oncology care pathway } \\
\text { expert from the Netherlands Comprehensive Cancer Organisation) }\end{array}$ \\
\hline 8 & Stakeholders select indicators & $\begin{array}{l}\text { Stakeholders from the BENCH-CAN project and other experts from cancer centers provided } \\
\text { feedback on the indicators }\end{array}$ \\
\hline \multirow[t]{2}{*}{9} & Measure the set of performance indicators & Data collection phase was 3 months \\
\hline & & $\begin{array}{l}\text { A team (consisting of the first author, other members of the BENCH-CAN consortium, and a } \\
\text { member of European Cancer Patient Coalition) performed a site visit to each pilot center to } \\
\text { verify the data, understand the context, and clarify any questions arising from the data }\end{array}$ \\
\hline 10 & Analyze performance differences & Deductive qualitative content analysis ${ }^{21}$ performed \\
\hline \multirow[t]{2}{*}{11} & $\begin{array}{l}\text { Take action: present results in a report and provide } \\
\text { recommendations }\end{array}$ & $\begin{array}{l}\text { For each participating cancer center, a report was prepared containing the anonymized outcomes } \\
\text { of the benchmark for all centers }\end{array}$ \\
\hline & & Improvement recommendations were sent in a separate document \\
\hline 12 & Develop improvement plans & If in agreement, pilot sites developed improvement plans \\
\hline 13 & Implement the improvement plans & Outside the scope of this study \\
\hline
\end{tabular}

Adapted from van Lent W, de Beer R, van Harten W. International benchmarking of specialty hospitals. A series of case studies on comprehensive cancer centres. BMC Health Serv Res 2010;10:253, with permission. 
Benchmarking Care Pathways and IPUs

and those from the cancer centers. ${ }^{17,18}$ Stakeholders of the BENCH-CAN project (eg, clinicians and [quality] managers) and experts from other cancer centers (OECI members, $n=71$ ) were then asked for feedback and a consensus was reached on the indicator set (step 8), containing 51 qualitative indicators and 193 quantitative indicators. Indicators assessed multiple topics concerning the organization of cancer care pathways, specifically those for breast and colorectal cancers, with a focus on organizational aspects of care pathways, not the clinical interpretation. Pilot sites appointed a team responsible for data collection covering multiple departments, including different stakeholder groups (ie, patients, clinicians, researchers, and management). Data were collected for the year 2012. After a quick data scan, a 1-day visit to each center was performed to verify the data, understand the context, and clarify questions arising from the data (step 9). Each visit consisted of semistructured interviews and a tour of the cancer center, with a specific focus on the breast unit (if available). The visits were also used to collect additional information and acquire feedback on the benchmark tool. The validity of the indicators was checked using feedback from pilot sites based on 3 criteria $^{19,20}$ : (1) clear definition, (2) data availability and reliability, and (3) discriminatory features.

\section{Analyses}

After the completion of all site visits, data for each indicator were compared. A deductive form of qualitative content analysis ${ }^{21}$ was used to report on the collected data (step 10). This method, which contains 9 separate steps from the benchmarking method tool, are described in Table 2.

Data in our study were anonymized, and pathway description was structured based on the criteria by Kinsman et al. ${ }^{22}$ Data analysis focused mainly on the pathway for breast cancer because all centers could present sufficient data, which allowed for comparison. Indicators developed for the pathway tool were based on the IPU criteria developed by Harvard Business School, ${ }^{23}$ such as organization of multidisciplinary teams (MDTs) and description of the steps taken in the development of the care pathway. To explore the degree of IPU development, every center was scored against these criteria (eg "organized around the patient medical condition or set of closely related conditions" and "co-located in dedicated facilities")

\begin{tabular}{|c|c|}
\hline Step & Action \\
\hline 1 & $\begin{array}{l}\text { Read through the (benchmark) data transcript, making notes } \\
\text { in the margins }\end{array}$ \\
\hline 2 & $\begin{array}{l}\text { Assess the notes made and list the different types of } \\
\text { information found }\end{array}$ \\
\hline 3 & Read through this list and categorize each item \\
\hline 4 & Repeat the first 3 stages again for each data transcript \\
\hline 5 & $\begin{array}{l}\text { Collect all of the categories or themes and examine each in detail } \\
\text { and consider the fit and relevance }\end{array}$ \\
\hline 6 & $\begin{array}{l}\text { Categorize all data (all transcripts together) into minor and major } \\
\text { categories/themes }\end{array}$ \\
\hline 7 & $\begin{array}{l}\text { Review all categories and ascertain whether some can be merged or } \\
\text { some need to be subcategorized }\end{array}$ \\
\hline 8 & $\begin{array}{l}\text { Return to the original transcripts and ensure that all the information } \\
\text { has been categorized }\end{array}$ \\
\hline 9 & $\begin{array}{l}\text { To ensure the validity, send a report containing all data to the pilot } \\
\text { sites for verification }\end{array}$ \\
\hline
\end{tabular}

(available at: https://www.isc.hbs.edu/health-care/vbhcd/pages/integrated-practice-units.aspx).

\section{Results}

\section{Indicators}

After data collection, definition clarity, data availability, data reliability, and discriminative value of the indicators were evaluated with the pilot centers. Based on this evaluation a total of 7 qualitative and 52 quantitative indicators were deemed irrelevant and removed, and 1 indicator regarding minimal volume of surgeries was added. This evaluation resulted in a final set of 45 qualitative indicators and 141 quantitative indicators that were considered suitable for wider use in benchmarking care pathways and exploring IPUs (supplemental eAppendix 1, available with this article at JNCCN.org).

\section{Pathway Benchmark}

An overview of the status of breast cancer pathways is provided in Table 3. Most cancer centers only started using official pathways recently; centers $D$ and $E$ had not implemented and formalized all pathways and were recommended to do so. Pathways are based on guidelines, either national or international, and have a clear "director" to guide development. All centers perform at least mammography, ultrasound, and physical examination before breast surgery, and all perform annual mammographies in the first 5 years of follow-up for all patients. However, center $\mathrm{E}$ indicated that they perform the follow-up for approximately $60 \%$ of their patients. Because mammography plays an important role in both 
Wind et al

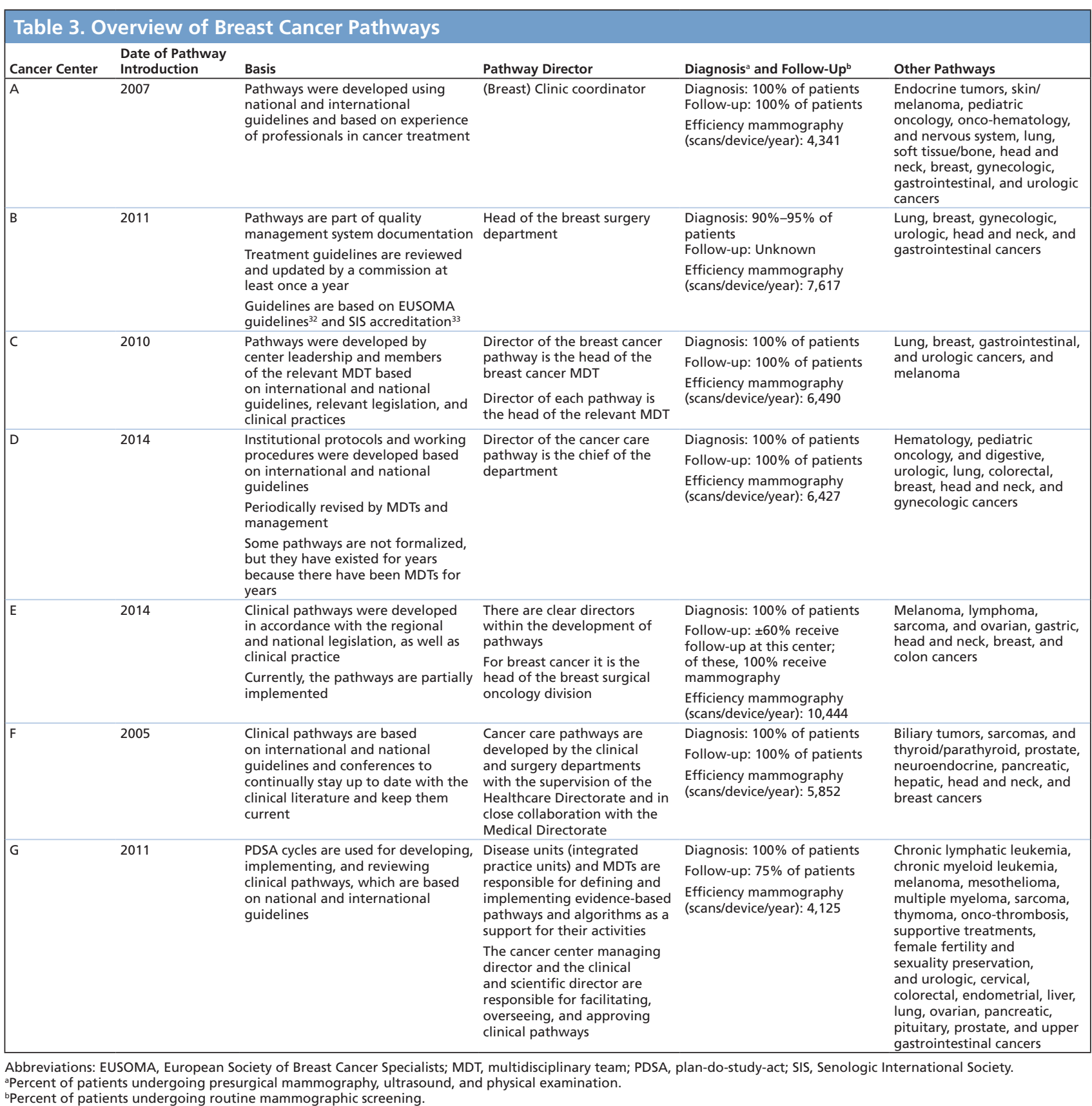

diagnosis and follow-up, efficient use of the machines is essential. The number of scans performed per device per year varied from 4,125 to 10,444 .

\section{Pathway Characteristics}

An overview of breast cancer pathway characteristics is provided in Table 4 . The pathways were developed for MDTs, with different roles for the various healthcare professionals. Center D was the least structured and was recommended to include discussion by an MDT in the pathway for all patients. Centers $\mathrm{E}$ and $\mathrm{F}$ were recommended to evaluate their protocol for patient transition to other healthcare facilities, because this was lacking in the formal pathway. In most countries, maximum waiting and throughput times for the different steps in the pathway were set by the government.

\section{Evaluation}

Table 5 shows that evaluation methods vary from an informal evaluation by MDTs to an extensive internal 
Benchmarking Care Pathways and IPUs

\begin{tabular}{|c|c|c|c|c|c|}
\hline Cancer Center & Multidis & ciplinary & $\begin{array}{l}\text { Guidelines or } \\
\text { Evidence Base }\end{array}$ & $\begin{array}{l}\text { Content of Pathway } \\
\text { Description }\end{array}$ & $\begin{array}{l}\text { Criteria for Waiting and } \\
\text { Throughput Times }\end{array}$ \\
\hline$A$ & $\begin{array}{l}\text { Care pathway describes } \\
\text { the roles of the } \\
\text { different disciplines } \\
\text { involved in the MDT } \\
\text { Formalized position }\end{array}$ & $\begin{array}{l}\text { Breast MDT core members: surgical and } \\
\text { medical oncology, radiotherapy, imaging, } \\
\text { pathology, and nursing } \\
\text { Non-core members: plastic surgery, } \\
\text { psycho-oncology, medical physics and } \\
\text { rehabilitation, genetics, neurosurgery, } \\
\text { orthopedics, and palliative care }\end{array}$ & $\begin{array}{l}\text { Pathways were developed } \\
\text { using national and } \\
\text { international guidelines }\end{array}$ & $\begin{array}{l}\text { Pathway describes all steps, } \\
\text { from patient admission } \\
\text { process and referral } \\
\text { requirements through } \\
\text { follow-up }\end{array}$ & $\begin{array}{l}\text { Pathway contains } \\
\text { maximum waiting times } \\
\text { between the various steps }\end{array}$ \\
\hline B & $\begin{array}{l}\text { Care pathway describes } \\
\text { the roles of the } \\
\text { different disciplines } \\
\text { involved in the MDT }\end{array}$ & $\begin{array}{l}\text { Breast MDT members: breast surgeons, } \\
\text { radiologists, medical oncologists, } \\
\text { radiotherapist, pathologist, geneticist, } \\
\text { nurse, and administrator }\end{array}$ & $\begin{array}{l}\text { Pathways are based on } \\
\text { well-known international } \\
\text { guidelines for breast } \\
\text { cancer (EUSOMA } \\
\text { guidelines) }\end{array}$ & $\begin{array}{l}\text { Pathway contains } \\
\text { information about } \\
\text { epidemiologic, scientific, } \\
\text { genetic, and clinical steps }\end{array}$ & $\begin{array}{l}\text { Government sets maximum } \\
\text { waiting times for certain } \\
\text { steps of the pathway }\end{array}$ \\
\hline C & $\begin{array}{l}\text { Care pathway describes } \\
\text { the roles of the } \\
\text { different disciplines } \\
\text { involved in the MDT }\end{array}$ & $\begin{array}{l}\text { Breast MDT members: breast surgeon, } \\
\text { clinical oncologist, plastic surgeon, } \\
\text { psychologist, imaging diagnostician, and } \\
\text { pathologist }\end{array}$ & $\begin{array}{l}\text { Pathways are based on } \\
\text { international guidelines, } \\
\text { such as } \mathrm{NCCN}^{34} \text { and ESMO } \\
\text { guidelines, and national } \\
\text { guidelines }\end{array}$ & $\begin{array}{l}\text { Pathway describes all steps, } \\
\text { from patient admission } \\
\text { through follow-up, } \\
\text { including all clinical } \\
\text { treatment algorithms }\end{array}$ & $\begin{array}{l}\text { Government does not limit } \\
\text { maximum waiting times in } \\
\text { general }\end{array}$ \\
\hline D & $\begin{array}{l}\text { Care pathway describes } \\
\text { the roles of the } \\
\text { different disciplines } \\
\text { involved and which } \\
\text { cases should be } \\
\text { presented in the MDT } \\
\text { meeting }\end{array}$ & $\begin{array}{l}\text { Breast MDT members: medical oncologist, } \\
\text { radiotherapist, radiologist, surgeon, and } \\
\text { pathologist }\end{array}$ & $\begin{array}{l}\text { Pathways are based on } \\
\text { international and national } \\
\text { guidelines }\end{array}$ & $\begin{array}{l}\text { Pathway describes all steps, } \\
\text { from patient registration } \\
\text { through follow-up, } \\
\text { including all clinical } \\
\text { diagnosis and treatment } \\
\text { algorithms }\end{array}$ & $\begin{array}{l}\text { Government only limits } \\
\text { the time from referral by } \\
\text { the general practitioner } \\
\text { to the time the specialized } \\
\text { physician sees the patient } \\
\text { There are currently } \\
\text { no standard means of } \\
\text { measuring waiting and } \\
\text { throughput times between } \\
\text { the steps in the pathway }\end{array}$ \\
\hline $\mathrm{E}$ & MDT for each pathway & $\begin{array}{l}\text { Breast MDT members, preoperative } \\
\text { setting: radiologist, surgeon, pathologist, } \\
\text { and breast nurse } \\
\text { Breast MDT members, postoperative } \\
\text { setting: surgeon, medical oncologist, } \\
\text { radiotherapist, pathologist, nuclear } \\
\text { medicine doctor, and breast nurse }\end{array}$ & $\begin{array}{l}\text { Pathways are based on } \\
\text { national and international } \\
\text { guidelines }\end{array}$ & $\begin{array}{l}\text { Pathway describes all steps, } \\
\text { from patient admission } \\
\text { process and referral } \\
\text { requirements through } \\
\text { follow-up }\end{array}$ & $\begin{array}{l}\text { Government decides on } \\
\text { maximum waiting times } \\
\text { between the steps within } \\
\text { the pathway }\end{array}$ \\
\hline $\mathrm{F}$ & $\begin{array}{l}\text { Care pathway describes } \\
\text { the roles of the } \\
\text { different disciplines } \\
\text { involved }\end{array}$ & $\begin{array}{l}\text { Breast MDT members: breast and } \\
\text { plastic surgeons, medical oncologists, } \\
\text { radiotherapists, geneticists, and } \\
\text { pathologists }\end{array}$ & $\begin{array}{l}\text { Pathways are based on } \\
\text { international and national } \\
\text { guidelines, clinical study } \\
\text { protocols, and conferences }\end{array}$ & $\begin{array}{l}\text { Pathway describes the } \\
\text { different steps taken in the } \\
\text { diagnostic and treatment } \\
\text { phases, and the available } \\
\text { clinical diagnosis and } \\
\text { treatment algorithms for } \\
\text { each of these steps; follow- } \\
\text { up is also described }\end{array}$ & $\begin{array}{l}\text { Government sets maximum } \\
\text { waiting times between } \\
\text { the various steps in the } \\
\text { pathway } \\
\text { Patient access to the } \\
\text { hospital is described and } \\
\text { monitored in the pathway }\end{array}$ \\
\hline G & $\begin{array}{l}\text { All participants in } \\
\text { MDTs were involved } \\
\text { in developing and } \\
\text { reviewing the clinical } \\
\text { pathways } \\
\text { Therefore, clinical } \\
\text { pathways are } \\
\text { integrated in the } \\
\text { activities of MDTs and, } \\
\text { vice versa, clinical } \\
\text { pathways include MDTs } \\
\text { as a crucial step }\end{array}$ & $\begin{array}{l}\text { Breast MDT members: surgeons, } \\
\text { oncologists, radiotherapists, pathologists, } \\
\text { and nurses } \\
\text { On call: radiologists, plastic surgeons, and } \\
\text { psychologists }\end{array}$ & $\begin{array}{l}\text { Pathways are based on } \\
\text { international and national } \\
\text { guidelines and conferences }\end{array}$ & $\begin{array}{l}\text { Pathway describes all steps, } \\
\text { from patient registration } \\
\text { through follow-up, } \\
\text { including all clinical } \\
\text { diagnosis and treatment } \\
\text { algorithms }\end{array}$ & $\begin{array}{l}\text { There are set waiting times } \\
\text { within the pathway; these } \\
\text { are monitored inside the } \\
\text { regional portal }\end{array}$ \\
\hline
\end{tabular}

Abbreviations: EUSOMA, European Society of Breast Cancer Specialists; MDT, multidisciplinary team; SIS, Senologic International Society.

and external evaluation. The clinical governance department at center A performs a patient pathway audit for every pathology clinic (IPU). The breast cancer pathway at center B was evaluated through external accreditation. At center $\mathrm{D}$, evaluation is performed internally and externally. At center E, the pathways were not systematically evaluated; an indicator matrix containing indicators from various sources was being developed for this purpose. At center F, pathways were collectively discussed through MDT meetings in close collaboration with the Healthcare Directorate and the Medical Directorate, who are in charge of supervising care pathways. Center $\mathrm{G}$ organized an extensive internal and external evaluation (by a regional and national agency). Overall pathway evaluation seems to focus mainly on waiting and throughput times and less on quality performance.

\section{IPU Development}

By definition, cancer centers are organized around a medical condition (ie, cancer). However, when differentiating and considering specific types of cancer, Table 6 shows that for breast cancer this can only be seen at center A (other than the breast IPU, this center has an IPU for 10 other cancer types), center B (breast cancer only IPU), and center G (IPU for 5 types of cancer, including breast). Table 6 shows the degree of implemen- 
Wind et al

Table 5. General Pathway Evaluation Policies

\begin{tabular}{|c|c|c|c|c|}
\hline Cancer Center & Evaluation Method & $\begin{array}{l}\text { Examples of Type of } \\
\text { Measurements }\end{array}$ & Frequency & Outcomes Evaluation \\
\hline \multirow[t]{3}{*}{ A } & \multirow{2}{*}{$\begin{array}{l}\text { Clinical governance conducts a patient pathway audit for every } \\
\text { pathology clinic, in which times between referral/appointment/ } \\
\text { diagnosing/treatment are evaluated, including reasons for delay }\end{array}$} & \multirow[t]{3}{*}{$\begin{array}{l}\text { Efficiency, clinical patient } \\
\text { outcomes }\end{array}$} & \multirow[t]{3}{*}{ Every trimester } & $\begin{array}{l}\text { Quarterly reports and an annual } \\
\text { report }\end{array}$ \\
\hline & & & & Another annual report with \\
\hline & Compliance with therapeutic guidance documents is also checked & & & $\begin{array}{l}\text { clinical indicators also compares } \\
\text { the results of the past } 2 \text { years }\end{array}$ \\
\hline B & $\begin{array}{l}\text { Evaluation of the breast pathway is performed by an external } \\
\text { evaluation body by means of accreditation }\end{array}$ & $\begin{array}{l}\text { Efficiency; each year } \\
\text { the pathway leadership } \\
\text { conducts or participates in } \\
\geq 2 \text { studies (eg, CP3R) that } \\
\text { measure quality and/or } \\
\text { outcomes }\end{array}$ & Once annually & $\begin{array}{l}\text { Outcome of the evaluation was a } \\
\text { structured pathway }\end{array}$ \\
\hline C & MDT members evaluate the applicable pathways & $\begin{array}{l}\text { Evaluation of patient flow } \\
\text { efficiency }\end{array}$ & Every 3 years & $\begin{array}{l}\text { Outcomes of the pathway } \\
\text { evaluation are discussed by } \\
\text { members of the relevant MDT and } \\
\text { included in the annual report }\end{array}$ \\
\hline \multirow[t]{4}{*}{ D } & Pathways are evaluated through review of patient files & \multirow{4}{*}{$\begin{array}{l}\text { Monitoring of patient } \\
\text { complaints, suggestions, } \\
\text { and diagnosis and } \\
\text { treatment guidelines } \\
\text { adherence, and evaluation } \\
\text { of quality of services }\end{array}$} & \multirow{4}{*}{$\begin{array}{l}\text { Internally every } \\
3 \text { months, } \\
\text { externally } \\
\text { quarterly }\end{array}$} & \multirow{4}{*}{$\begin{array}{l}\text { The quality-of-care team and the } \\
\text { external evaluation reports are } \\
\text { presented to the center's medical } \\
\text { council and the general manager } \\
\text { As a result of the evaluation, the } \\
\text { responsible parties are informed } \\
\text { of their individual performance } \\
\text { and provided with suggestions for } \\
\text { improvement }\end{array}$} \\
\hline & There are no goals set beforehand & & & \\
\hline & $\begin{array}{l}\text { Internal evaluation is performed by } 2 \text { means: quality-of-care control } \\
\text { team and internal audit }\end{array}$ & & & \\
\hline & $\begin{array}{l}\text { External evaluation is performed by the national healthcare } \\
\text { insurance }\end{array}$ & & & \\
\hline \multirow[t]{2}{*}{$\mathrm{E}$} & $\begin{array}{l}\text { Pathways were not systematically monitored; they will be monitored } \\
\text { through specific indicators }\end{array}$ & \multirow{2}{*}{$\begin{array}{l}\text { EUSOMA's indicators for } \\
\text { breast unit; BENCH-CAN } \\
\text { indicators }\end{array}$} & \multirow[t]{2}{*}{ Not applicable } & \multirow[t]{2}{*}{ Not applicable } \\
\hline & $\begin{array}{l}\text { To date, proposed indicators are EUSOMA's indicators for breast unit } \\
\text { accreditation, integrated with internal performance indicators and } \\
\text { indicators proposed by BENCH-CAN }{ }^{14}\end{array}$ & & & \\
\hline \multirow[t]{3}{*}{$\mathrm{F}$} & $\begin{array}{l}\text { Medical Directorate coordinates the activities for the evaluation of } \\
\text { diagnostic and therapeutic pathways (PDTA) }\end{array}$ & \multirow{3}{*}{$\begin{array}{l}\text { Efficacy and efficiency } \\
\text { of pathways measured } \\
\text { through evaluation } \\
\text { of clinical outcomes } \\
\text { (eg, mortality rates, } \\
\text { readmissions, external } \\
\text { audits) and quality } \\
\text { outcomes (eg, adherence } \\
\text { to the PDTA, customer } \\
\text { satisfaction) }\end{array}$} & \multirow[t]{3}{*}{ Every 6 months } & \multirow{2}{*}{$\begin{array}{l}\text { Findings from the evaluation } \\
\text { process are implemented by the } \\
\text { clinical and surgery departments } \\
\text { in order to translate results into } \\
\text { practice }\end{array}$} \\
\hline & \multirow[t]{2}{*}{$\begin{array}{l}\text { The evaluation process is performed inside the center in close } \\
\text { collaboration with the clinical and surgery departments and under } \\
\text { supervision of the Healthcare Directorate }\end{array}$} & & & \\
\hline & & & & $\begin{array}{l}\text { Quality, Training, and Privacy } \\
\text { Office coordinates the quality } \\
\text { improvement process of the } \\
\text { pathways in close collaboration } \\
\text { with the departments }\end{array}$ \\
\hline \multirow[t]{9}{*}{ G } & External evaluation: & \multirow{9}{*}{$\begin{array}{l}\text { 30-day mortality, } \\
\text { readmissions, surgical } \\
\text { reinterventions, transfers } \\
\text { to other acute hospitals, } \\
\text { efficiency (eg, percentage } \\
\text { of patients operated } \\
\text { on within } 60 \text { days from } \\
\text { mammography) }\end{array}$} & \multirow{4}{*}{$\begin{array}{l}\text { Continuous } \\
\text { improvement } \\
\text { Small/relevant } \\
\text { every year as } \\
\text { evidence changes } \\
\text { Formally/big } \\
\text { every } 3 \text { years }\end{array}$} & \multirow{9}{*}{$\begin{array}{l}\text { Several actions are implemented } \\
\text { to improve outcomes and quality } \\
\text { provided to patients as a result of } \\
\text { the pathway evaluation } \\
\text { In breast cancer, for example, } \\
\text { starting from the group of } \\
\text { evaluation indicators, there is } \\
\text { continuous improvement with } \\
\text { an annual evaluation visit by } \\
\text { EUSOMA }\end{array}$} \\
\hline & centers (regional and national) & & & \\
\hline & $\begin{array}{l}\text { Regional benchmarks for single hospital performance against other } \\
\text { regional hospitals }\end{array}$ & & & \\
\hline & $\begin{array}{l}2 \text { types of evaluation are provided: } \\
\text { - General evaluation at the department level } \\
\text { - Evaluation on the pathway level }\end{array}$ & & & \\
\hline & $\begin{array}{l}\text { The national evaluation is performed by a national agency that } \\
\text { once a year displays on a Web portal the outcome measures (eg } \\
\text { mortality), benchmarked against all national hospitals }\end{array}$ & & & \\
\hline & Internal evaluation: & & & \\
\hline & $\begin{array}{l}\text { Internal system calculates and provides all performance indicators to } \\
\text { the hospital }\end{array}$ & & & \\
\hline & $\begin{array}{l}\text { Review of clinical pathways is based on a periodical review of } \\
\text { patient records }\end{array}$ & & & \\
\hline & $\begin{array}{l}\text { Planning is in process to include the pathways inside the EPR system } \\
\text { in order to facilitate clinical decisions and improve standardization }\end{array}$ & & & \\
\hline
\end{tabular}

team; PDTA, Diagnostic-Therapeutic-Healthcare Protocol; SIS, Senologic International Society.

tation of the IPU features, scored with a 3-point system. This is linked to the common organization unit where, in all centers, providers involved are members of the cancer center, but in center A, B, and G they are members of a specific organizational unit.

All centers work with tumor-specific MDTs, hence dedicating time to the specific condition. Members of the MDT are however not always solely or clearly dedicated to one tumor type or unit. A physician heads the MDT, although only centers E and $G$ have a dedicated case manager.

Regarding responsibility for the full care cycle, this was the case for MDTs in all centers. Nevertheless, only centers $A$ and $G$ indicated that the unit encompassed rehabilitative care and supporting services (eg, psychosocial services). For other centers, these were part of services for the whole center, as were patient education, engagement, and follow-up, which are seen as integral to care but not specifically arranged for a unit (except 
Benchmarking Care Pathways and IPUs

\section{Table 6. Degree of Development of Breast Cancer IPUs Based on Criteria}

\begin{tabular}{|c|c|c|c|c|c|c|c|}
\hline \multirow[b]{2}{*}{ Criterion } & \multicolumn{7}{|c|}{ Cancer Center } \\
\hline & A & B & $\mathrm{C}$ & D & $\mathrm{E}$ & $\mathbf{F}$ & $\mathbf{G}$ \\
\hline Organized around a medical condition & +++ & +++ & ++ & ++ & ++ & ++ & +++ \\
\hline MDT with dedicated time to the condition & +++ & +++ & ++ & ++ & ++ & ++ & +++ \\
\hline $\begin{array}{l}\text { Providers involved are members of or affiliated with a common } \\
\text { organizational unit }\end{array}$ & +++ & ++ & ++ & ++ & ++ & ++ & +++ \\
\hline Physician team captain or clinical care manager oversees care process & ++ & ++ & + & + & ++ & + & +++ \\
\hline $\begin{array}{l}\text { Providers function as a team, meeting formally and informally on a regular } \\
\text { basis }\end{array}$ & +++ & +++ & +++ & +++ & +++ & +++ & +++ \\
\hline $\begin{array}{l}\text { Responsibility for the full cycle of care for the condition, encompassing } \\
\text { outpatient, inpatient, and rehabilitative care, as well as supporting services } \\
\text { (eg, nutrition, social work, behavioral health) }\end{array}$ & +++ & ++ & ++ & ++ & ++ & ++ & +++ \\
\hline $\begin{array}{l}\text { Incorporates patient education, engagement, and follow-up as integral } \\
\text { to care }\end{array}$ & +++ & + & + & + & + & + & +++ \\
\hline $\begin{array}{l}\text { Measures outcomes, costs, and processes for each patient using a common } \\
\text { information platform }\end{array}$ & +++ & + & + & + & + & + & +++ \\
\hline Accepts joint accountability for outcomes and costs & +++ & & & & & & +++ \\
\hline Single administrative and scheduling structure & +++ & + & ++ & + & + & + & +++ \\
\hline Co-located in dedicated facilities & +++ & +++ & +++ & +++ & +++ & +++ & +++ \\
\hline Total degree of implementation out of 33 & 32 & 21 & 19 & 18 & 19 & 18 & 33 \\
\hline
\end{tabular}

A triple plus symbol (+++) indicates that the feature is fully developed, a double plus symbol (++) indicates that the feature is mostly developed, and a single plus symbol (+) indicates that the feature is partially implemented. Blank cells indicate that the criterion could not be assessed.

Abbreviations: IPUs, integrated practice units; MDT, multidisciplinary team.

for centers A and G). However, center $G$ mentioned that many patients admitted to the unit already have a diagnosis and many complete follow-up elsewhere. This compromises the measurement of outcomes of the entire care pathway for each patient.

All centers measure outcomes, costs, and processes; however, most $(n=5)$ do this for the whole center and not for specific units. Because the IPU-related definition of "outcomes that most matter to patients" is not specified, and consensus-based International Consortium for Health Outcomes Measurement sets ${ }^{24}$ were not yet available for breast cancer at the time of measurement, we could not establish whether this was actually the case. Two centers, however, reported that they have patient-based focus groups and measure breast cancerspecific process indicators and outcomes and use this feedback to improve care provision.

Centers are either lacking data platforms that allow for the collection of specific inputs (in terms of human resources and finances) and outcomes per unit, or do not currently collect these data. Similarly, specific administrative and scheduling structures were lacking or not fully implemented, because centers C, D, E, and F do not have a formalized unit. Although center $\mathrm{B}$ indicated they have a breast IPU, whether they have an accompanying dedicated scheduling structure was unclear.

Overall, 3 types of centers can be identified: those that have the IPU structure implemented (centers $A$ and $G$ ), those that have the IPU partially implemented (center B), and those that have certain features of the IPU but did not develop or implement the IPU (centers C, D, E, F). IPU imple- mentation outcomes for the breast unit in center $\mathrm{A}$ are described in supplemental eAppendix 2.

\section{Discussion}

This study developed a benchmark tool to assess development, implementation, and evaluation of cancer care pathways. The tool was successfully tested in 7 cancer centers to assess its suitability for yielding improvement suggestions regarding pathway organization and providing data for exploring the status of IPU organization.

The director concerned with pathways is usually a medical specialist, which is in accordance with the assertion of Polite et $\mathrm{al}^{9}$ that the responsibility for oncology pathway development must always lie primarily with clinicians. Our data suggest that centers have no clear strategy when developing pathways, which is consistent with the findings of Vanhaecht et $\mathrm{al},{ }^{8}$ who showed that a minority of sampled countries (43\%) used a systematic approach to develop, implement, and evaluate care pathways. None of the centers work with previously established goals for pathway evaluation. In-built continuous evaluation and follow-up should guarantee the effectiveness of care pathways, ${ }^{25}$ and was therefore recommended as an improvement opportunity for cancer centers.

Porter ${ }^{26}$ stated that care pathways are beneficial but not sufficient for delivering value-based, high-quality care and recommended the establishment of IPUs. In this explorative study assessing the centers' benchmark data against the criteria of an IPU, ${ }^{20}$ we identified 3 groups. Group 1, consisting of centers fully meeting all 
criteria (centers $A$ and $G$ ), and group 2, consisting of centers partially meeting the criteria (center B), both reported having a breast IPU. Based on our data, we agree that centers $\mathrm{A}$ and $\mathrm{G}$ have an IPU for breast cancer. However, for center B, improvements in 4 criteria are required to have a fully implemented IPU. Group 3, consisting of centers meeting only some of the criteria, did not report having an IPU. The fact they meet some of the criteria is likely due to the pathway organization and the organization of MDTs (which are key features of an IPU) that has been developed for years. ${ }^{27}$ Dedicating specific resources, such as staff to measure outcomes specific to the IPU and IPU-specific administrative and scheduling systems, were lacking or not fully implemented. Centers were recommended to improve registration of patient outcomes using permanent patient-based input, both for clinical (eg, securing stateof-the-art treatment innovations, introducing cognitive testing for side effects on brain functioning as a consequence of chemotherapy) and organizational aspects (eg, determining the impact of waiting on a diagnosis or treatment on a patient's quality of life). Measuring outcomes "that matter most to patients" requires improvement in all centers; however, this is a continuously developing objective and requires a permanent or periodic update involving patient input.

Sarai et $\mathrm{al}^{28}$ identified IPUs as units in which providers commit a substantial portion of their time to treating a focused set of care pathways, implying that pathways are IPU building blocks. In our study, we used pathways as tools to map current organizational processes and identified areas to improve these processes where necessary (value and quality improvement on the process level). IPUs are structured organizational units in which the process identified through the pathway occurs. IPU organization seems to require an organizational change from a focus on disciplinebased departments (eg, radiotherapy) to those departments facilitating the IPUs, which are pathway-based. In this study, IPUs are therefore seen as tools for quality and value improvement on a strategic level.

Evaluation of the breast IPU in center A showed that improved efficiency led to more time available for patients, trough higher volumes, economies of scale, and improvements in quality. Although based on a small number, this corresponds to findings by Low et $\mathrm{al}^{29}$ who found that IPUs resulted in reduced readmissions among patients at highest risk of readmission. Enthoven et $\mathrm{al},{ }^{30}$ however, argue that for patients with multiple morbidities, the IPU concept is unfavorable. This stems from the original ideas of Porter and Teisberg ${ }^{10}$ that IPUs should be entities with sufficient degrees of "selforganization." No published information exists on how patients feel about this development, which needs to be known in order to facilitate true patient-centered care.

Developing and implementing an IPU has barriers, which will vary based on the condition being treated, provider organization, and health system characteristics. Keswani et $\mathrm{al}^{31}$ divided these barriers into 3 subcategories: operational, technology, and payment/contracting. Supplemental eAppendix 3 provides an overview of the barriers.

This study has several limitations. First, we did not emphasize the detailed clinical content of the pathway. Future research focusing on the exact pathway content as part of the benchmark will further enable international knowledge-sharing. Furthermore, because the initial focus of the indicators was pathways, we had to deduct the IPU criteria from the material. This assessment was aided by focusing the site visits on breast cancer departments, which showed whether centers had the IPU organization in place. Indicators that specifically examine IPU organization should be refined and could help provide a more thorough assessment based on IPU criteria. This study only focused on breast cancer; future studies should include patient cohorts that have shared medical (and social) needs. Additionally, because few scientific publications are available, some degree of subjectivity was inevitable in the explorative assessment of the benchmark data against the IPU criteria. Further studies of scale and cutoff points that distinguish between different levels of IPU development are recommended.

This study's evaluation of an IPU for breast cancer care showed performance improvements in terms of efficiency and finances. Future research focusing on more extensive (patient) outcome evaluation over multiple years will allow comparison between IPU-organized and non-IPU-organized cancer centers to determine whether IPUs add value and actually decrease costs for the health system.

Finally, this study focused on a limited number of cancer centers $(n=7)$ and collected data for 1 year, with all of the centers located in Europe, although the original theory stems from the United States. However, although health and financing systems differ, the findings are likely applicable in the United States. Future research should include larger series 
Benchmarking Care Pathways and IPUs

(including general hospitals with an oncology department) in multiple countries (including different continents) and over multiple years to assess actual discriminative capabilities of the tool and establish the sensitivity for changes over time.

\section{Conclusions}

We successfully developed and piloted a benchmark tool to compare and elaborate on organizational performance, and provided recommendations for improving the organization of cancer care pathways (both implementation and evaluation). The data generated through the benchmark enabled exploration of the status of IPU development. Pathways can be seen as the process that occurs in the strategic unit of the IPU. Our assessments found that centers varied in fulfilling IPU criteria, usually lacking specific resources such as staff; in measuring IPUspecific outcomes; and in their IPU-specific administrative and scheduling systems. Development of an IPU requires a strategic organization change with several implications for operations, technology, and payment and contracting.

\section{References}

1. Porter ME, Lee TH. The Strategy That Will Fix Health Care. Available at: https://hbr.org/2013/10/the-strategy-that-will-fix-health-care. Accessed August 2, 2018 .

2. Mohr JJ, Batalden $P$, Barach P. Integrating patient safety into the clinical microsystem. Qual Saf Health Care 2004;13(Suppl 2):ii34-38.

3. Wulff CN. The Effect of Hospital-Based Case Management in Cancer Care Pathways [dissertation]. Aarhus, Denmark: Aarhus University; 2012.

4. Institute of Medicine. Crossing the Quality Chasm: A New Health System for the 21st Century. Washington, DC: National Academy Press; 2001.

5. Preston C, Cheater F, Baker R, Hearnshaw H. Left in limbo: patients' views on care across the primary/secondary interface. Qual Health Care 1999;8:16-21.

6. De Bleser L, Depreitere R, De Waele K, et al. Defining pathways. J Nurs Manag 2006;14:553-563.

7. Currie L, Harvey G. The Origins and Use of Care Pathways in the USA, Australia and the United Kingdom. Report 15. Oxford, England: Royal College of Nursing Institute; 1998.

8. Vanhaecht K, Bollmann M, Bower K, et al. Prevalence and use of clinical pathways in 23 countries - an international survey by the European Pathway Association. Int J Care Coord 2006;10:28-34.

9. Polite BN, Page RD, Nabhan C. Oncology pathways-preventing a good idea from going bad. JAMA Oncol 2016;2:297-298.

10. Porter ME, Teisberg EO. Redefining Health Care: Creating Value-Based Competition on Results. Boston, MA: Harvard Business Review Press; 2006.

11. Keswani A, Koenig KM, Bozic KJ. Value-based healthcare: part 1designing and implementing integrated practice units for the management of musculoskeletal disease. Clin Orthop Relat Res 2016;474:2100-2103.

12. Pollock RE. Value-based health care: the MD Anderson experience. Ann Surg 2008;248:510-516.

13. Mosel D, Gift B. Collaborative benchmarking in health care. Jt Comm J Qual Improv 1994;20:239.

14. BENCH-CAN. Available at: http://www.oeci.eu/Benchcan/. Accessed March 23, 2016.

15. OECI Accreditation and Designation Programme. Available at: http:// oeci.selfassessment.nu/cms/. Accessed August 7, 2016.

16. van Lent W, de Beer R, van Harten W. International benchmarking of specialty hospitals. A series of case studies on comprehensive cancer centres. BMC Health Serv Res 2010;10:253.

17. van Hoeve J, de Munk L, Otter R, et al. Quality improvement by implementing an integrated oncological care pathway for breast cancer patients. Breast 2014;23:364-370.

18. van Hoeve JC, Elferink MA, Klaase JM, et al. Long-term effects of a regional care pathway for patients with rectal cancer. Int J Colorectal Dis 2015;30:787-795.

19. De Korne DF, Sol KJ, van Wijngaarden JD, et al. Evaluation of an international benchmarking initiative in nine eye hospitals. Health Care Manage Rev 2010;35:23-35.
20. Cowper J, Samuels M. Performance Benchmarking in the Public Sector: The United Kingdom Experience. Available at: http://www.oecd.org/ unitedkingdom/1902895.pdf. Accessed August 2, 2018.

21. Zhang Y, Wildemuth BM. Qualitative Analysis of Content. Available at: https://www.ischool.utexas.edu/ yanz/Content_analysis.pdf. Accessed September 15, 2016.

22. Kinsman L, Rotter $\mathrm{T}$, James $\mathrm{E}$, et al. What is a clinical pathway? Development of a definition to inform the debate. BMC Med 2010;8:31.

23. Integrated Practice Units: Organizing Care Around Medical Conditions. Institute for Strategy \& Competitiveness, Harvard Business School Web site. Available at: http://www.isc.hbs.edu/health-care/vbhcd/pages/ integrated-practice-units.aspx. Accessed August 19, 2016.

24. The International Consortium for Health Outcomes Measurement (ICHOM). ICHOM Standard Set for Breast cancer, 2017. Available at: http://www.ichom.org/medical-conditions/breast-cancer/. Accessed March 5, 2017.

25. de Vries M, van Weert JC, Jansen J, et al. Step by step development of clinical care pathways for older cancer patients: necessary or desirable? Eur J Cancer 2007;43:2170-2178.

26. Porter ME. Value-based health care delivery. Presented at the Value Based Health Care Center Europe Event; April 10, 2014; Nijkerk, the Netherlands. Available at: http://vbhcprize.com/wp-content/ uploads/2014/03/Porter-Value-based-health-care-delivery.pdf. Accessed August 14, 2016.

27. Taylor C, Shewbridge A, Harris J, Green JS. Benefits of multidisciplinary teamwork in the management of breast cancer. Breast Cancer (Dove Med Press) 2013;5:79-85.

28. Sarai M, Duszak R, Kaufman JA. Value-based medicine: organizing IR care through integrated practice units. J Vasc Interv Radiol 2016;27:336-338.

29. Low LL, Tan SY, Ng MJ, et al. Applying the integrated practice unit concept to a modified virtual ward model of care for patients at highest risk of readmission: a randomized controlled trial. PloS One 2017; 12:e0168757.

30. Enthoven AC, Crosson FJ, Shortell SM. 'Redefining health care': medical homes or archipelagos to navigate? Health Affairs 2007;26;1366-1372.

31. Keswani A, Koenig KM, Ward L, Bozic KJ. Value-based healthcare: part 2-addressing the obstacles to implementing integrated practice units for the management of musculoskeletal disease. Clin Orthop Relat Res 2016;474:2344-2348.

32. European Society of Breast Cancer Specialists. Guidelines. Available at: https://www.eusoma.org/en/guidelines/1-107-1-. Accessed August 22, 2018.

33. Senologic International Society. SIS/ISS International Breast Centers Accreditation. Available at: http://www.sisbreast.org/accreditation/ibca/. Accessed August 22, 2018.

34. Gradishar WJ, Anderson BO, Aft R, et al. NCCN Clinical Practice Guidelines in Oncology: Breast Cancer. Version 1.2018. Accessed August 22, 2018. To view the most recent version of these guidelines, visit NCCN. org

35. Senkus E, Kyriakides S, Ohno S, et al. Primary breast cancer: ESMO clinical practice guidelines. Ann Oncol 2015;26(Suppl 5):v8-30. 